\title{
OFFICE PRACTICE
}




\section{MACMILLAN MASTER SERIES}

Banking

Basic English Law

Basic Management

Biology

British Politics

Business Communication

Chemistry

COBOL Programming

Commerce

Computer Programming

Computers

Data Processing

Economics

Electrical Engineering

Electronics

English Grammar

English Language

English Literature

French

French II
German

Hairdressing

Italian

Keyboarding

Marketing

Mathematics

Modern British History

Modern World History

Nutrition

Office Practice

Pascal Programming

Physics

Principles of Accounts

Social Welfare

Sociology

Spanish

Statistics

Study Skills

Typewriting Skills

Word Processing 


\section{MASTERRITH}

\section{OFFICE PRACTICE}

SECOND EDITION

PAUL BAILEY

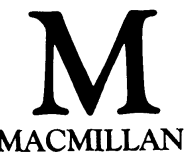


๑) Paul Bailey 1982, 1985

Line drawings $\odot$ Macmillan Education Ltd 1982, 1985

All rights reserved. No reproduction, copy or transmission of this publication may be made without written permission.

No paragraph of this publication may be reproduced, copied or transmitted save with written permission or in accordance with the provisions of the Copyright Act 1956 (as amended).

Any person who does any unauthorised act in relation to this publication may be liable to criminal prosecution and civil claims for damages.

First edition 1982

Reprinted 1982, 1983 (twice), 1984

Second edition 1985

Published by

MACMILLAN EDUCATION LTD

Houndmills, Basingstoke, Hampshire RG21 2XS

and London

Companies and representatives

throughout the world

Typeset in Great Britain by

Tec Set, Sutton, Surrey

British Library Cataloguing in Publication Data

Bailey, Paul, 1937 Dec. 29-

Mastering office practice.-2nd ed.-

(Macmillan master series)

1. Office practice

I. Title

651 HF5547.5

ISBN 978-0-333-38848-8 ISBN 978-1-349-07876-9 (eBook)

DOI 10.1007/978-1-349-07876-9 


\section{CONTENTS}

Preface

xii

Acknowledgements

xiii

1 The office in its

1.1 Defining an office

1

environment

1.2 Definition of common terms

1.3 Business ownership

2

1.4 Departments in business organisations

2 Layout of business letters

2.1 Letter styles

2.2 Parts of a business letter

2.3 Composing letters

2.4 Addressing

2.5 Memorandum forms

2.6 Form letters

2.7 Reports

2.8 Carbon copy notation

3 Handling the mail

3.1 Incoming mail

3.2 Outgoing mail

3.3 Circulars

3.4 Stamping mail

3.5 Reference books in the mail room

3.6 Other mail room equipment 36

4 Mail - choosing the best

4.1 Post Office services method

4.2 Inland post 39

4.3 Overseas letter services 46

4.4 Inland parcels 47

4.5 Overseas parcels 49

4.6 Railway services 50

5 Telecommunications

5.1 The telephone 55

5.2 Using the telephone 56

5.3 Telephone rates 57

5.4 Recorded information services 57

5.5 Making telephone calls 58

5.6 Answering the telephone 58

5.7 Telephone messages 59

5.8 The telephone alphabet 60 
5.9 Using the firm's telephone for private calls

5.10 Switchboards

5.11 Telephone call services

64

5.12 Types of telephone

69

5.13 Confravision

5.14 Videostream

5.15 Telephone answering machines

5.16 Telephone answering and recording machines

5.17 Telex

5.18 Private teleprinter service $\quad 72$

5.19 Telex call offices 73

5.20 Using a telex 73

5.21 Data transmission 74

5.22 Data transmission facilities $\quad 75$

5.23 Merlin DX 78

5.24 Electronic mail - Teletex $\quad 80$

5.25 Prestel and MicroNet $800 \quad 80$

5.26 Facsimile communications systems

6 Shorthand and audio systems

7 Typewriters

8 Computers
6.1 Shorthand

6.2 Audio-typing

6.3 Centralised systems

6.4 Hygiene

6.5 Machine shorthand

7.1 Manual typewriters

7.2 Care of manual machines

7.3 Erasing/correcting using a manual machine

84

85

88

90

90

91

92

93

7.4 Electric machines 94

7.5 Electronic typewriters 95

7.6 Type sizes 98

7.7 Printing 99

7.8 Ribbons 99

7.9 Care of electric and electronic typewriters 100

7.10 Attachments and accessories 101

8.1 Mainframe computer $\quad 104$

8.2 Minicomputer 104

8.3 Microcomputer 105

8.4 Main components of computers 105

8.5 Central processing unit $\quad 107$ 
8.6 Memory 107

8.7 Screens (Visual Display Units) 108

8.8 Keyboards 109

8.9 Printers 110

8.10 Paper handling $\quad 112$

8.11 Storage media $\quad 113$

8.12 Handling programs and data $\quad 116$

8.13 Memory size 118

8.14 Some computer terms $\quad 118$

8.15 Some computer applications $\quad 120$

8.16 Computer care $\quad 122$

8.17 Word processing $\quad 124$

8.18 Dedicated word processors $\quad 124$

8.19 Using a dedicated word processor 126

8.20 Microcomputers with a word processing program $\quad 128$

8.21 Visual integrity 132

8.22 The difference between dedicated word processors and computers with a wordprocessing program

8.23 The advantages of wordprocessing systems over typewriters

8.24 Typesetting from word processors 134

8.25 Training 135

8.26 Spreadsheets $\quad 135$

8.27 Databases 136

8.28 Graphics 136

8.29 Future developments $\quad 136$

8.30 Data Protection Act $1984 \quad 137$

9 The purchase and sale of $\quad 9.1$ Documents used in a business goods

9.2 Selling goods 140

9.3 The sale of goods - quotation of prices or trade terms $\quad 142$

9.4 Ordering goods $\quad 144$

9.5 Receiving goods $\quad 146$

9.6 VAT 149

9.7 Debit note 151

9.8 Credit note 151

9.9 Statements $\quad 152$

9.10 Payment $\quad 154$

9.11 Receipt $\quad 154$ 
9.12 Business accounts

9.13 Buying and selling overseas 155

9.14 Overseas payment 157

9.15 The distribution of goods 157

10 Mechanical aids

11 Stock control

12 Methods of payment

13 The petty cash

14 Filing

15 Meetings
10.1 Computers

11.1 Keeping adequate stock $\quad 165$

11.2 Storage of goods

166

11.3 Stock records

166

12.1 Registered mail $\quad 170$

12.2 Bank services 170

12.3 Bank services for the private individual

171

12.4 Current account services 171

12.5 Other bank services 182

12.6 Glossary of terms 183

12.7 Post Office services 184

12.8 Credit cards 190

12.9 Points to note 191

12.10 The future 192

13.1 The imprest system 194

13.2 The petty cash not using the imprest system 198

14.1 The reasons for storing correspondence and records $\quad 200$

14.2 Filing terms 201

14.3 Filing - first considerations 201

14.4 Methods of classifying

14.5 Indexing 209

14.6 Filing equipment - systems 215

14.7 Microfilming 220

14.8 Punched tape and card 224

14.9 Filing - some general hints and terms

14.10 Reminder systems - tickler files

14.11 Computerised filing 226

15.1 Kinds of meetings 228

15.2 Holding a meeting 231

15.3 Other meeting terms 234

15.4 The duties of a committee secretary 
16 Appointments

17 Office Stationery
16.1 The desk diary

16.2 Travel itinerary

17.1 Paper

245

17.2 Envelope sizes

17.3 Carbon paper

18 Copying and duplicating

18.1 Copying

18.2 Photocopying

18.3 Laser printers

259

18.4 Heat processes

260

18.5 Dual-spectrum

260

18.6 Transfer processes

260

18.7 Diazo (Dyeline)

261

18.8 Choosing an office copier

262

18.9 Duplicating processes

263

18.10 Spirit duplicating

264

18.11 Ink duplicating

267

18.12 Offset litho

272

18.13 Copyright

274

19 The training and qualifi-

19.1 Public examinations cations required for office work

19.2 Part-time study

19.3 General qualifications

278

19.4 Computer operator

279

19.5 Filing clerk

280

19.6 General clerk

280

19.7 Office machine operator 280

19.8 Receptionist 280

19.9 Secretary 281

19.10 Telephonist

282

19.11 Telex operator

282

19.12 Typist

282

19.13 Word processor operator

283

20 Finding and applying for a job
20.1 Finding the right job

20.2 Applying for a job

20.3 If you are invited to attend for an interview 285

20.4 Interviews 286

20.5 Starting a new job 286

20.6 Contract of employment 287

20.7 Personal file 287

20.8 Leaving a job 288

20.9 Acts of Parliament affecting employment
284 284 
21 The law relating to employment
21.1 Health, safety and working conditions

21.2 Safety in the office

21.3 Security in the office

21.4 Equipment

21.5 Information

297

21.6 The Royal Society for the Prevention of Accidents

22 Wages, salaries and other

22.1 A wage

22.2 Clock or time cards

22.3 The wages clerk

22.4 Gross pay

22.5 A salary

22.6 Deductions from wages and salaries

22.7 Calculating tax deductions

22.8 Tax deductions or refunds

22.9 National insurance

22.10 Changing a job

22.11 Certificate of pay and tax deductions

22.12 Return of P11

22.13 Absence from work through illness

22.14 Voluntary deductions

22.15 The payment of wages and salaries

22.16 Payment into a bank or building society account

22.17 Pay in hand

22.18 Flexitime

23.1 Memory aids

23.2 General information

23.3 Outside reference sources

23.4 Reference books

23.5 Telecommunications sources

24.1 Basic display kit

24.2 Bar graphs

24.3 Charts

24.4 Line graphs

24.5 Maps

24.6 Typed tables

24.7 Models

24.8 Colour transparencies
299

300

300

300

300

302

304

306

306

310

312

312

312

313

313

313

315

315

316

316

317

317

321

323

324

326

328

328

330

330

330 
Appendices
A.1 Correction signs
332

A.2 Miscellaneous items

333

Index 


\section{PREFACE}

This second and revised edition of Mastering Office Practice takes full account of all the recent developments in new office technology and provides a comprehensive text covering all the elementary and intermediate examinations in Office Practice, Clerical Duties, Secretarial Duties and Secretarial Practice, and the theory sections of all Word Processing and Information Processing examinations including those of The Royal Society of Arts, the London Chamber of Commerce and Industry and the Business and Technical Education Council. It is suitable for students taking all public examinations connected with the office and its environment and it is appropriate for those involved in commercial and information technology teacher training.

It has been written in a style which is easy to read and understand, and in such a manner as to enable teachers and students to come to terms with the rapid changes which are taking place in the office and its connected worlds. The chapters have built-in Activity sections which are designed to test knowledge and understanding to date and to suggest areas for further discussion and individual research. Questions are offered at the end of each section/chapter, together with some projects. It is expected that teachers and students will be selective about the activities and projects undertaken, but each one is designed to be of value to the student compiling a portfolio which will be of practical value when at work.

The author has provided a comprehensive framework which will enable teachers and students to expand and develop individual ideas and interests while simultaneously preparing students for public examinations and the practical problems associated with office and secretarial work. The chapters on telecommunications and computers are, in particular, relevant to all students and not just those taking office/secretarial examinations while those relating to job qualifications, the law relating to employment, wages and other forms of remuneration and giving sources of information, taken with the telecommunications and computer chapters, can form the backbone of any life and social skills course.

This book has been written by a practising teacher and examiner for teachers and students and throughout the text is the thread of the new microchip-based technology and the increasingly important telecommunications networks.

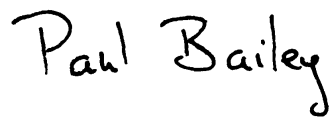




\section{ACKNOWLEOEEMENTS}

It is impossible for any one individual to produce a book of this nature without much support, and the author is indebted to those who have supplied him with details of latest developments and so enabled the text not only to be up to date but also predict future developments.

The author and publishers wish to thank the following who have kindly given permission for the use of copyright material: Banda, Berol Ltd, Commodore, Expandex Ltd, Gestetner Ltd, IBM UK Ltd, International Timex Ltd, Lanier Business Products, Her Majesty's Stationery Office, Midland Bank plc, Nashua Copycat Ltd, National Girobank, Pitney Bowes plc, The Post Office, British Telecom, Rexel Ltd, Spicers Ltd, Swift Business Equipment Ltd, Twinlock UK Ltd, 3M UK Ltd, Kodak Ltd, Olympia International. 